\title{
Seramik Sanatçısı Velimir Vukicevic ve Çözümsüz Bulmacaları
}

Yeşim ZÜMRÜT*

Özet

Gerçek bir nesnenin duyular üzerindeki izlenimlerinin yanlış değerlendirilmesi olarak tanımlanan illüzyon ya da yanılsama, özellikle Optik sanatın temel öğesi ve pek çok sanatçı için de esin kaynağı olmuştur. Görsel etkileme gücüyle öncelikle resim, grafik, tekstil alanında olmak üzere medya, mimari ve moda gibi pek çok alanda karşımıza çıkan yanılsama, seramik sanatçısı ve eğitimci Prof. Velimir Vukicevic'in porselen eserlerinde de çarpıcı bir şekilde kullanılmıştır. Bu makalede, uluslararası arenada çok sayıda ödül kazanan, sanatsal etkinliklere katılan, önemli koleksiyonlarda eserleri yer alan sanatçının eğitimci kişiliği, eserleri ve genel anlamda seramik sanatına bakışı ele alınmıştır.

Anahtar Sözcükler: Velimir Vukicevic, Optik Sanat, Yanılsama, Porselen, Seramik.

\section{Ceramic Artist Velimir Vukicevic and His Unresolved Puzzles}

\section{Abstract}

Illusion or misconception, defined as misinterpretation of impressions of a tangible matter on senses, has become the major element of optic art and an inspiring source for many artists. Illusion as a strong visual highlight, which we encounter in many fields such as fashion, architecture and media including painting and graphic textile, has been distinctively utilized in the porcelain works of Prof. Velimir Vukicevic. This article highlights the artist's works, his specific view of ceramic art and his educational personality as an artist who has been awarded many international prizes, who has attended artistic events, and whose works have been displayed in important collections.

Keywords: Velimir Vukicevic, Optic Art, Illusion, Porcelain, Ceramic. 


\section{Giriş}

Illüzyon ya da yanılsama, genelde nesnelerin ya da içinde bulundukları mekanın gerçek sanılabilecek kadar asıına uygun olarak betimlenmesidir. 20. yüzyıl sanat ve estetik yazınında doğalcılığın temel ilkelerinden biri olarak kabul edilir. Terim, dar anlamında perspektif ve kısaltım gibi resimsel tekniklerin gözü aldatacak boyutlarda kullanımını içerir (Eczacıbaşı 3, 1997: 1914).

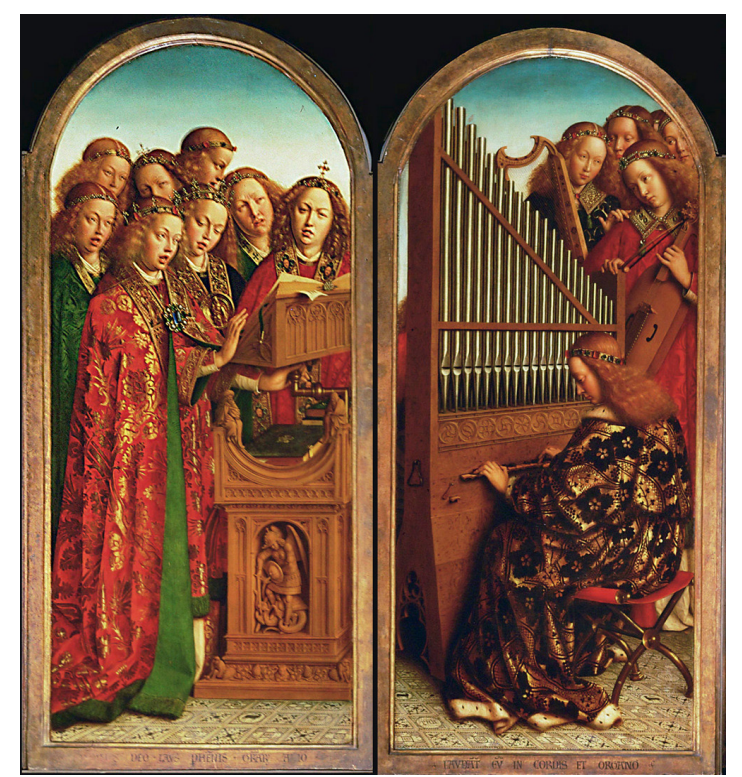

Resim 1.Jan Van Eyck“Müzik Çalan ve Şarkı Söyleyen Melekler”, $161 \times 69 \mathrm{~cm}, 1432$.

Altdorfer'in 'Meryem ve Melekler' tablosundaki meleklerin sonsuzluğa uzanan diziliminde, Jan Van Eyck'in 'Müzik Çalan ve Şarkı Söyleyen Melekler' tablosundaki meleklerin saçlarının her bir telinde, ahşabın ince liflerinde, kumaşın her ipliğini hissetmemizi sağlayan yanılsamada bizi avuçlarının içine alan psikolojik bir tepkidir. İnsanın reddedemeyeceği şekilde, doğrudan algıyı hedefleyen ve kesinlikle dikkat çekmeyi başaran bu yanılsamalar, Gombrich'in (1992) Sanat ve Yanılsama başlıklı kitabında 'vesaire-ilkesi' olarak adlandırılmıştır. Bu ilkeye göre, bir zincirin birkaç halkasını algıladığımızda, zincirin bütününü gördüğümüzü varsayarız. İnsan zihni verilen olgulara fazla dikkat etmeden varsayımlara gitmeye yönlendirilebilir; bu da çok ilginç yanılsamalara yol açabilir. "Bu bağ- lamdaki en ünlü yanılsama, Fraser sarmalıdır; gerçekte bu bir sarmal olmayıp, odak noktaları aynı bir dizi daireden oluşma bir bütündür." (Gombrich, 1992: 214).

Yanılsamanın temel öğe olduğu 'Optik Sanat'ta ise, izleyicinin varlığı bir ön koşul olarak değerlendirilirken, aynı zamanda kişiye göre değişmeyen ortak bir algı anlayışı benimsenir. Yapıtın görsel etkisi direkt olarak gözün retina tabakasında oluşturulur, böylece yapıta bakan herkes benzer bir duyumsamaya yönlendirilir. Burada kullanılan araç, bir yandan renk algısı teorilerine ve renk psikolojisine dayanırken, bir yandan da biçimsel bir yanılsama alanıdır. Rönesans ressamlarının kullandıkları düzlemsel perspektifin yanılsama olasılıklarının bir tekrarıdır (Özmen, 2010: 3).

Bir çizimde mekan ve derinlik adına okuduğumuz her şey bir yanılsama ürünüdür. Çizgi, biçim, değerler ve dokular belli bir düzen içinde bir araya getirildiklerinde, boşluktaki üç boyutlu formların mekansal düzenini ifade etme potansiyeline sahiptirler. Her şey görsel sistemimizin çizilmiş imgeyi nasıl yorumladığına bağlıdır. Çizimlerimizde üç boyutlu formları bir mekan içinde göstermek ve bir derinlik vermek istiyorsak, yanılsama sanatında ustalaşmamız gerekir (Ching, 2003: 9). Göz, beyin, nesne ve ortam birlikteliği ile ortaya çıkan görsel algıda yanılsamayı yaratan en önemli etkenlerden biri görmenin objektif değil sübjektif olmasıdır (Avcı Tuğal, 2012: 27). Aslında olmayan bir şey yanılsaması yaratan bir nesne, imge veya tasarım, izleyiciyi kasıtlı bir şekilde şaşırtmak ya da mesajı yorumlayabilecek hedef kitleye yönelik bir bilgi sağlamak amacıyla kullanılabilir (Ambrose vd., 2005: 126).

Görsel yanılsamaların aklı yanıltmasını sağlamak için renklerden, çizgilerden ve biçimlerden yararlanılır. İki ve üç boyutlu nesneler ışığın ve insan gözünün sebep olduğu yanılsamalarla bir takım oyunlar oluşturur. Takip eden çizgiler, açık koyu renkler, geometrik etkiler yanılsamaya sebep olan temel öğelerdir. Ortaya koyulan eserin yanı sıra seyircinin işi izlemesi de yanılsamayı algılamada etkendir. İzleyicinin hareketliliği ya da heykellerin mobil olmasından kaynaklı sabit olmama durumu yanılsama etkisini arttırır. Aynı zamanda malzeme çeşitliliği de bu etkiyi 
arttıran bir öğe olarak karşımıza çıkar (Resim 2-5).

Görsel etkileme gücüyle medyada, grafik, tekstil, resim, mimari, moda gibi pek çok alanda karşımıza çıkan yanılsama, seramik sanatında da gerek form gerek yüzey

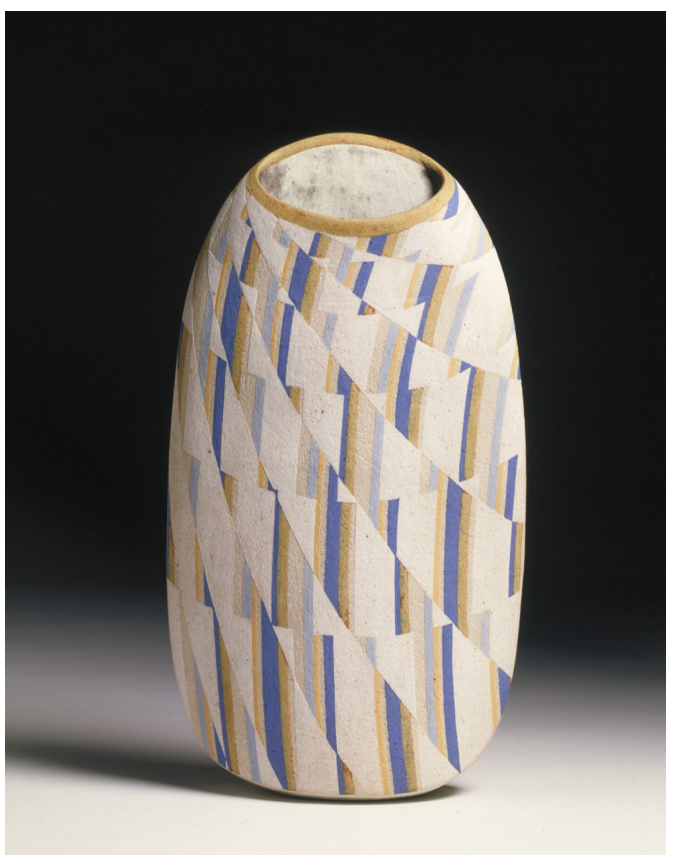

Resim 2. Elizabeth Fritsch.

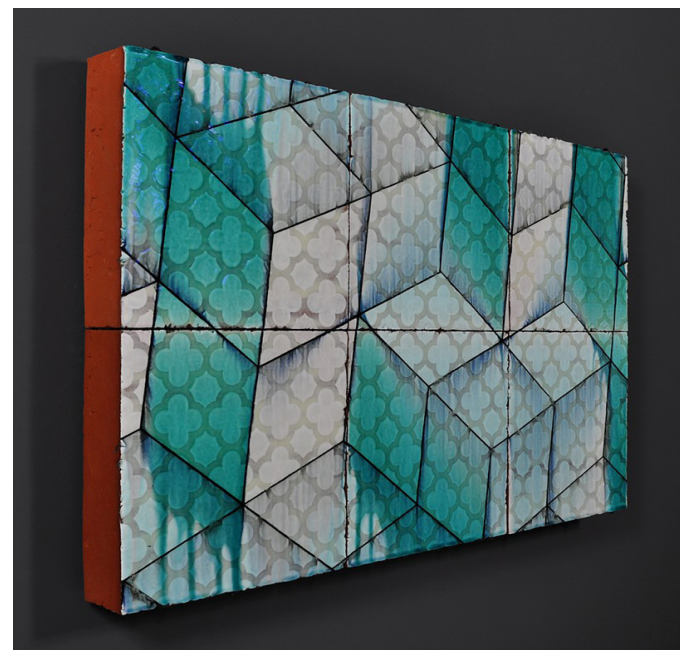

Resim 3. Jason H Green.

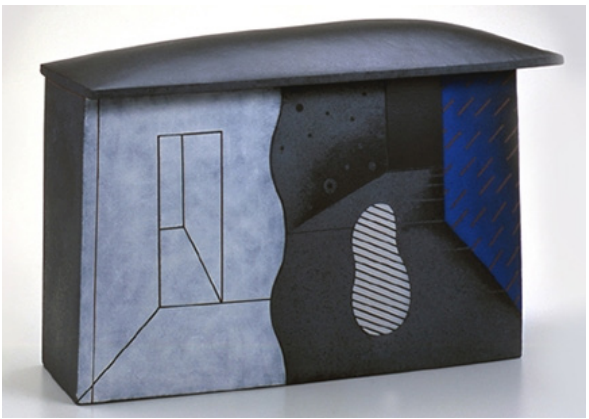

Resim 4. Yasuo Hayashi.

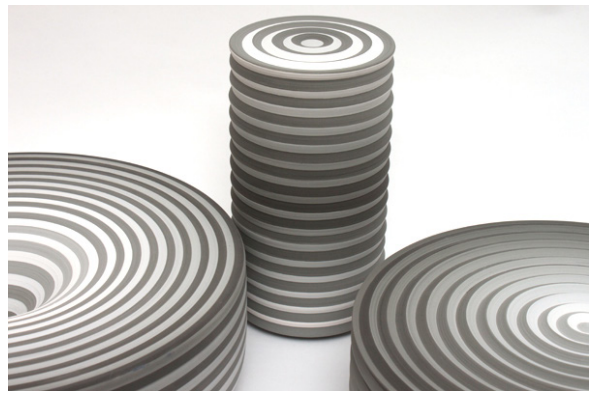

Resim 5. Jin Eui Kim.

tasarımında önemli bir öğe olmuştur. Yanılsamayı seramik eserlerinde özgün bir şekilde kullanan sanatçılara; seramik form yüzeylerine çizdiği desenlerde seçtiği biçim, ton değerleri ve renklerle kendisinin de ifade ettiği gibi iki buçuk boyutluluk algısı yaratan Elizabeth Fritsch (http://www.vam.ac.uk/content/articles/c/ceramicspoints-of-view-elizabeth-fritschs-optical-pot/, 2014), iki boyutlu seramik karoların yüzeyindeki üç boyutlu geometrik kurgularıyla Jason H Green, eğrisel küpleri ve açık ve koyu alanlar ile yarattı̆̆ı iç geometrik alanları ile Yasuo Hayashi, yatay ve dikey olarak konumlandırdı̆̆ı ve işlevsel olmayan silindir formlarında, degrade geçişlerle mekansal yanılsamalar oluşturan Jin Eui Kim, çizgi değerlerinin ve negatif pozitif algının öne çıktığı seramikleriyle Simcha Even-Chen, ters imaj tekniğiyle şekil-zemin ilişkisinde farklı anlamlar kazdıran Greg Payce örnek verilebilir (Re$\operatorname{sim} 6-7)$.

\section{Velimir Vukicevic ve Çözümsüz Bulmacaları}

Bu grupta değerlendirilebilecek bir diğer önemli isim de, 2012 yılında II. Uluslararası Gölcük Seramik 


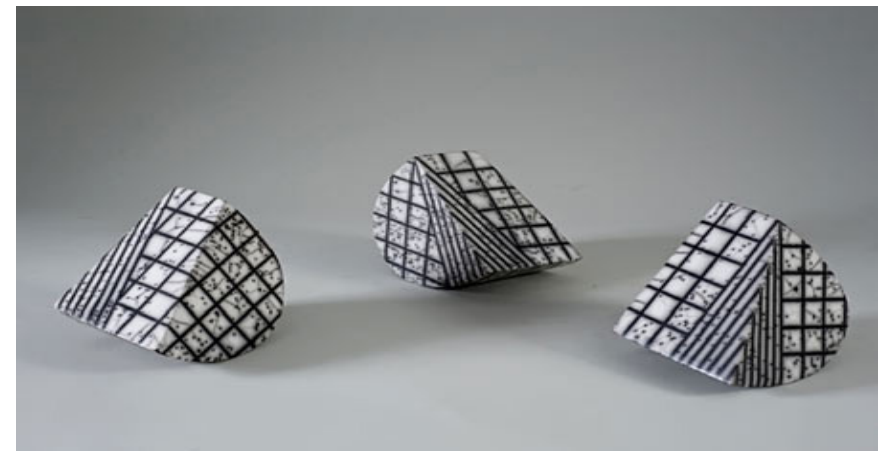

Resim 6. Simcha Even-Chen

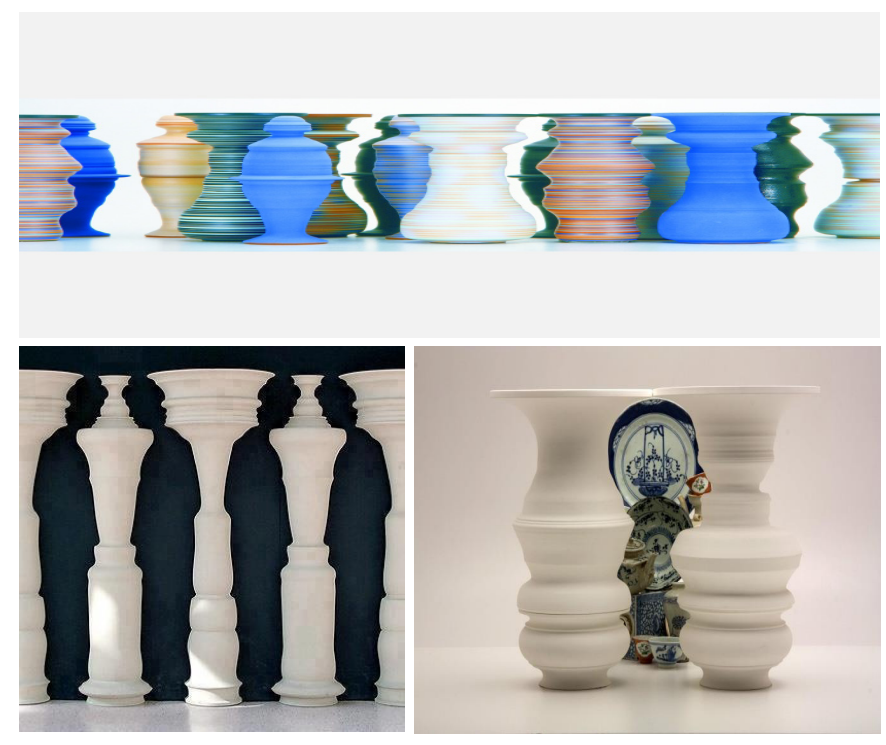

Resim 7. Greg Payce

Sempozyumu'nda beraber çalıştığımız, 1950 Sırbistan/ Belgrad doğumlu sanatçı-eğitimci Prof. Velimir Vukicevic dir. Babası da seramik sanatçısı olan Vukicevic, kendini hatırladığı günden beri seramik sanatı ile iç içe büyümüştür. Bu anlamda çoğu kişiye göre daha şanslı olduğunu düşünen sanatçı, seramik ile yoluna devam edebilmesi için gerekli olan tüm malzemelere sahip bir atölyeyle birlikte, ailesinden sonsuz destek almıştır. 1974'te Belgrad Uygulamalı Sanatlar Fakültesi Seramik Bölümünden mezun olmuş ve aynı fakültede yüksek lisansını, doktorasını bitirmiştir (http://www.arts.bg.ac.rs/rektoraten/, 2014). 1992'den itibaren Belgrad Sanat Üniversitesi'nde seramik heykel profesörü olarak çalışan ve çok sayıda uluslararası workshop’a, sergilere katılan, ödüller alan Vukicevic, eğitim ile geçen yıllarını ve sonrasını “Orada estetik ve teknik anlamda temel bilgileri öğrendim. Bunun sonrasında kendi çalışma şeklime ve özgün ifade biçimime uygun kişisel tekniğimi geliştirdim" (Vukicevic, 2014: Internet ortamında yapılan röportaj, 03 Nisan.) sözleriyle ifade eder.

Sırbistan'da yalnızca tek bir Uygulamalı Sanatlar Fakültesi bulunmaktadır. Bu fakülte Tiyatro, Sinema, Müzik ve Güzel Sanatlar Fakültesi ile birlikte Belgrad Sanat Üniversitesi'ne bağlıdır. Seramik bölümü altmış yıldır var olan bir bölümdür. Temel çalışmalar için 4 yıl + 1 yıl yüksek lisans + doktora programı uygulanan bölümde, Seramik-Heykel, Seramik Tasarımı ve Çömlekçi Tornasında Şekillendirme olmak üzere üç ana dal bulunur. Klasik bir eğitim anlayışına sahip olan okulda, öğrencilerin her biri atölyelerde uygulama yapmaya başlamadan önce çizim yapmayı ve boyamayı öğrenmek zorundadır. Her yıl 10 öğrenci alan seramik bölümüne son yıllarda ilgi azalmıştır. Bunun en önemli nedeni ülkemizde de yaşadığımız bir sorun olan mezun olduktan sonra özel atölye malzemelerinin ciddi maliyet gerektirmesi ve bu alanda çalışabilmeyi zorlaştırmasıdır. Seramik bölümünde, seramik-heykel alanında eğitim veren Vukicevic'in eğitimci olarak en çok önem verdiği şeylerden biri, öğrencilerinin kendi yollarında kişisel ifade biçimlerini ve bireyselliklerini geliştirmelerine yardımcı olmaktır.

Yurtdışında farklı sanatçılarla birçok sergi ve workshoplara katılan sanatçı Sırp seramik sanatının dünya ölçeğinde bulunduğu konumu şu sözlerle ifade eder:

"Sırbistan gibi küçük bir ülkeden geldiğinde diğerleriyle iletişim kurman gerekir. Açık, kışkırtıcı ve değişim konusundaki yenilikçi anlayışı ile uluslararası sergilere katılım sanatçılar için bir teşviktir. Çünkü uluslararası alanda düzenlenen bu etkinlikler; yeni eğilimleri gözlemlemek, diğer sanatçılarla ya da farklı kültürel çevrelerle iletişime geçerek onların çalışma yöntemlerini görmek onları karşılaştırmak için bir fırsat verir. Günümüzde Sırp seramikleri, derin ahlaki ve ekonomik krizlere rağmen canlılık göstermektedir. Seramik sanatının mevcut durumunu genelleyebilmek mümkün değildir. Her sanatçı kendi tarzını ortaya koymaya çalışır. Seramik heykel, kullanım eş- 
yası ya da tasarım ürünü olarak seramikten çok daha kışkırtıcı bir disiplin olarak ortaya çıkar. Son yirmi yıl boyunca ülkede hakim olan genel atmosfer düşünüldüğünde neşeli, yaratıcı, bazen de esprili fikirler ile ifade bulan seramikler arasındaki fark inanılmaz derecede şaşırtıcıdır. Beklide moralimizi yüksek tutmak için bize yardımcı olan çok çalışmak olmuştur. Bunun sonucunda, Sırp seramikleri çok çağdaş, canlı ve taze yapısıyla geldiği noktada, Mino, Faenza, Kore vb. en rekabetçi sergilerde, uluslararası sahnede hak ettiği yeri almıştır." (Vukicevic, 2014: Internet ortamında yapılan röportaj, 03 Nisan).

Genel tanımıyla sanatçı, evreni, çevreyi, toplumu, insanı hiçbir ayrım gözetmeksizin algılama ve duyumsama zorunluluğunda olan, duyarlılığı keskinleşmiş kişidir. Bu algılamalar sonunda elde ettiği verileri, bir estetik tavır, bir sanatsal amaç ve büyük bir ustalıkla yoğurup yorumlayıp tekrar insanlığa aktarır. Bazı sanatçılar, yetenekleri, sezgileri, cesur ruhları, vizyonları, merakları ya da teknolojik bilgileri sayesinde bir çeşit kültürün dönüşümlü gelişim aracı olma yükünü de üzerlerine alırlar.

Teknolojik gelişmeler, yeni malzemeler, toplumdaki değişimler, sanat teorisi ile sanat pratiği arasındaki dengede ve estetik değerlendirmelerdeki değişimleri de beraberinde getirir. Sanatçılar kimi zaman özgür iradeleri ile bu değişikliklere karşı koyar ya da desteklerler. Vukicevic'e (2014) göre “Sanat ne statik ne de izoledir. Sürekli bir değişim içindedir. Değişimler kendilerinde gelişmeyi öngörürler. Ancak, sanatta inişler ve çııışlar, daha iyi ve daha az başarılı dönemler her zaman vardır.".

Mimari, resim, grafik sanatı, heykel ya da fotoğraf gibi sanat alanlarının kendi aralarında olduğu gibi seramik ile aralarındaki sınırlarında değişken olduğunu, seramik sanatının içinde seri üretim ile özgün sanat eserleri arasında sürekli bir yeniden incelemenin var olduğunu düşünen sanatçlya göre:

"Seramik sanatı, izin verilen genel anlayış ve değişen kuralların bir sonucu olarak kendi kimliğini kaybetme riski altındadır. 21. yüzyıl tasarımın ve görsel saldırganlığın aşırı olduğu bir dönemdir. Pazarın taleplerini karşılamak için sanatçılar sık sık görsel niteliklerden yoksun esprili bir bakış açısı ile geri çekilirler. Seramik malzemenin doğası ve teknolojik süreçleri sayesinde görsel sanat özelliğini koruması için hala bir şansı vardır. Bu da diğer sanatlar üzerindeki bir avantajı olabilir." (Vukicevic, 2014: Internet ortamında yapılan röportaj, 03 Nisan).

Sanatsal bir amaca sahip olması ve bir kimlik oluşturması beklenen sanatçı, her şeyden önce sanatsal kaygısını estetik bir dille, özgürce ve özgün üslupla ifade edebilmelidir. Genel anlamda sanatçıdan beklenen kendine uygun bir sanat dili seçmesidir. Vukicevic'in sanatsal üslubu yalın ve kuvvetli, malzemeye ve kullandığı tekniklere hakimiyeti son derece etkilidir.

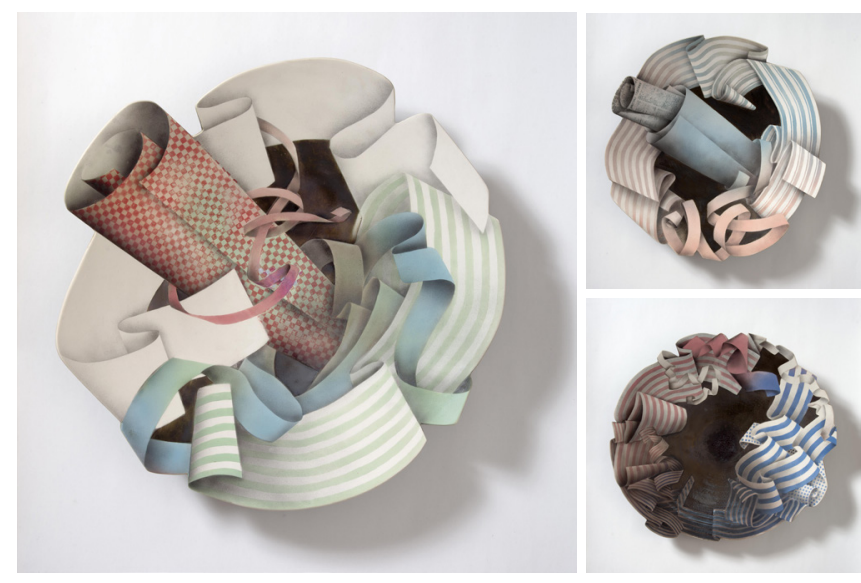

Resim 8. Velimir Vukicevic, ‘Dönen Yanılsama' Tabaklar Serisinden, 2013-2014

Sanatçının heykellerine baktığımızda, gerek yapıtın oluşumunda kullanılan birimlerin yalınlığı ile gerek maksimum etkiyi yaratacak şekilde özenle seçilen renk-çizgibiçim ile gördüğümüz gerçekliğin ya da ustaca yaratılmış bizi içine alan optik bir yanılsamanın içinde savruluruz. Algı ve anlaşılmanın ötesinde görsel deneyimi ön plana taşıyan formlardan oluşan eserlerinde, rengarenk astarlar, sır üstü boyaları ve çıkartmalar kullanarak; kıvrılmış kurdeleler, rulo kağıtlar, gazete kupürleri, piramitler, silindirler, iç içe geçmiş çizgiler, ustaca belirlenmiş açık koyular ve perspektif yanılsamalar ile yaratılan derinliğin içinde uzay ve mekan algısını kaybederiz (Resim 8-10). 

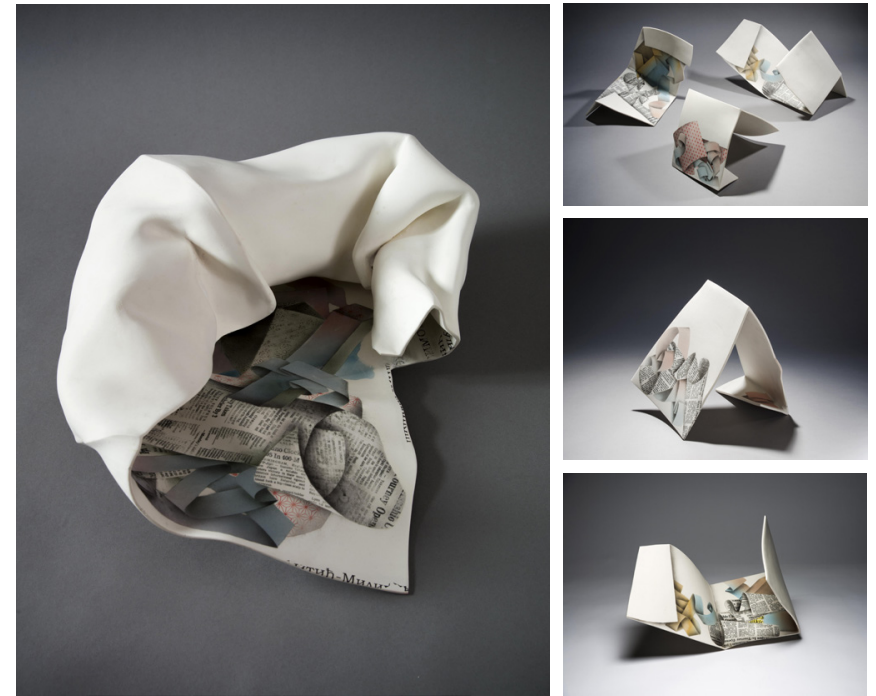

Resim 9. Velimir Vukicevic, Kutular Serisi, 2013-2014

Her biri çözümsüz birer bulmaca gibi olan porselen heykeller ve çeşitli porselen tabak dizileri çalışan sanatçıya göre, başa çıkılması gereken en önemli mesele seramik şekillendirme yöntemlerinin iki önemli özelliğini uyumlu bir şekilde bağdaştırabilmektir. Bunlar, yüzeylerin modellenmesi ve boyanmasıdır. Sanatçının tüm eserleri tornada, döküm tekniğiyle veya plaka tekniği ile şekillendirilmiş, astarlarla boyanmış porselenlerdir. Yüzey dekorlarında uygulanan siyah gölgeler, maskeleme yöntemi kullanılarak pistole yardımıyla oluşturulur. Sanatçı çoğu zaman $1250^{\circ}{ }^{\circ}$ 'de birkaç kez pişirim yapar. Bazen de bir heykelin parçalarını ayrı ayrı çalışarak fırınlar ve sonrasında epoksi yapıştırıcı yardımıyla bir araya getirir. Genellikle üç veya dört benzer çalışmanın bir araya geldiği düzenlemeler yapar (http://velimirvukicevic.com/, 2014). Vukicevic, günümüzde fikrin kendi başına çalışmadan çok daha önemli hale geldiğini düşünür. Sanatçı porselen eserlerini tamamladıktan sonra eserin alt metnini ekleyebileceğini ancak çalışmalarını hayal ettiğinde ve onlar için eskizler yaptığında sadece estetik olup olmadıklarını ve sanal yanılsamalar için hangi formun daha uygun olduğunu düşündüğünü ifade eder (Resim 11).

Vukicevic'in çalışmalarında perspektif yanılsamalarla merdivenlerden tırmanan, bir düzlemden başka bir düzleme geçen, sonsuz derinliklerde optik seyahatler eden izleyici için yapıyı terk etmek çokta mümkün gözükmemektedir (Radic, 1999: 6). Sonsuzluk ihtimali ile birlikte sunulan bulmacanın çözümü ya da çıkış yeri hiçbir yorumda bulunmamaktadır. İzleyicileri yönlendirmek ya da dikkatlerini çekmek için orada bulunan spiraller: merkeze ya da merkezden dışarıya bir tur demektir. Sanatçı bu noktada Chuang Tzu ${ }^{1}$ gibi düşündüğünü ifade eder “Bir kelebek olduğumu hayal eden ben miyim, yoksa kelebek mi ben olduğunu hayal eden?" (Vukicevic, 2014: Internet ortamında yapılan röportaj, 3 Nisan).
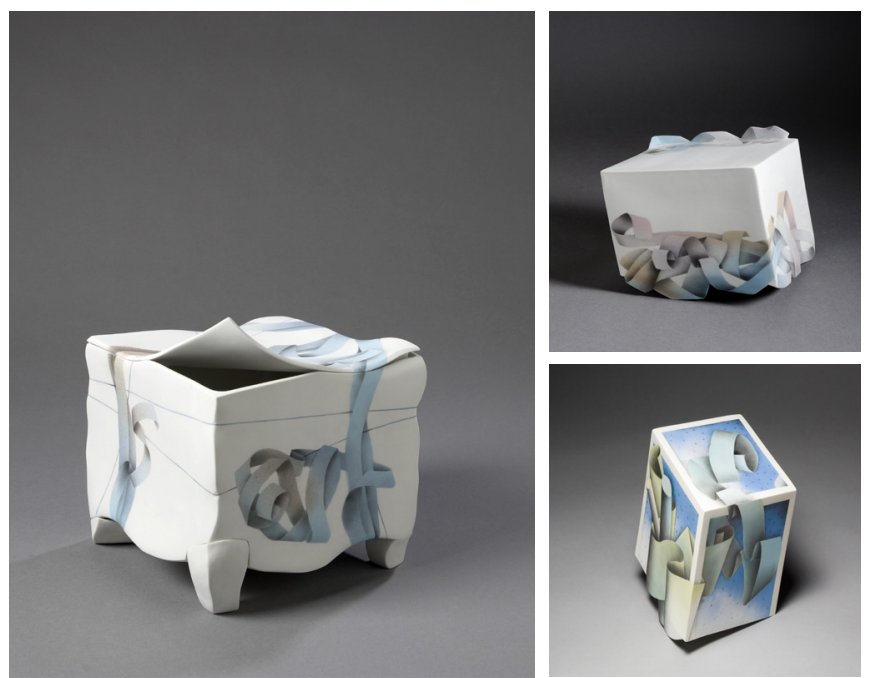

Resim 10. Velimir Vukicevic, Kutular Serisi, 2013-2014
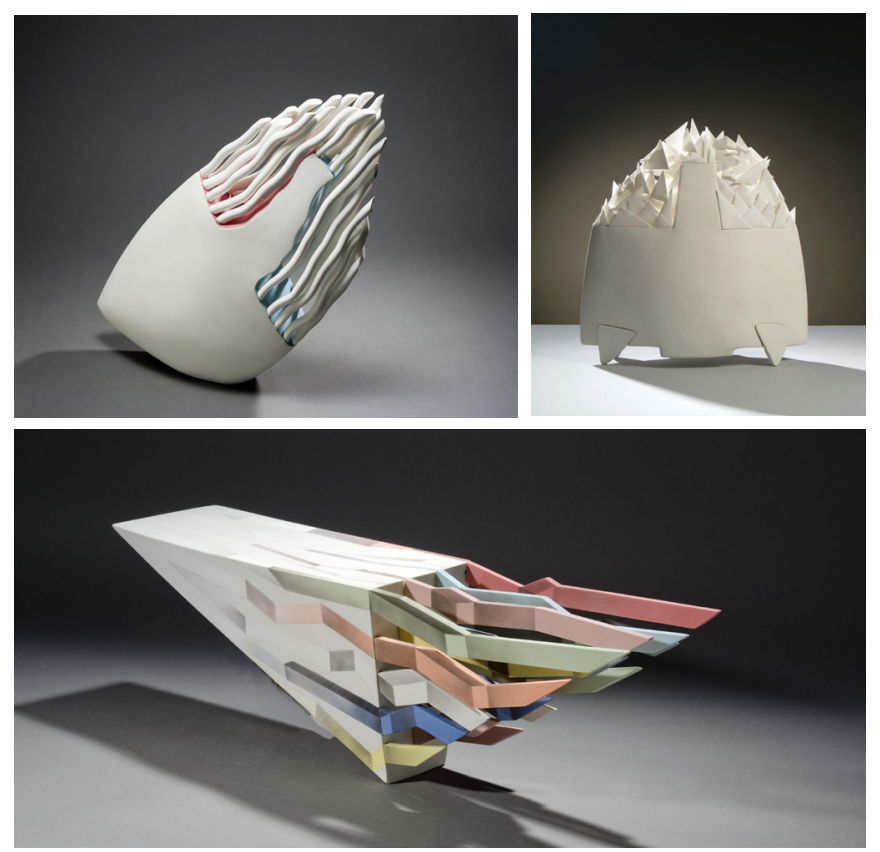

Resim 11. Velimir Vukicevic, Porselen Heykeller, 2013-2014 
Diğer sanatçıların eserleriyle her zaman ilgili olan, uluslararası yarışma kataloglarını, seramik dergilerini, internetteki seramik çalışmalarını-haberlerini incelemek ve takip etmek için çok zaman harcayan sanatçı, iletişimin bu şekline çok önem vermektedir. En çok Japon seramik sanatçılarının uygulamalarını beğenen ve kendisi gibi yanılsama üzerine çalışan Yasuo Hayashi hayranı olan Vukicevic, Çek sanatçı Jindra Vikovayı, kendisinden tamamen farklı çalışmasına rağmen Rafa Perez, Marc Leuthold, Bodil Manz, Suehary Fukami, Hoshino Satory, Matsumoto Hideo gibi sanatçıların çalışmalarını takdirle takip etmektedir. II. Uluslararası Gölcük Seramik Sempozyumu'nda beraber çalıştığı sanatçılar dışında Türk seramik sanatı hakkında çok az şey bildiğini ifade eden sanatçı, Türk seramik sanatçılarından Alev Ebuzziya Siesbye'in, Kore'de tanıştığı ve ortak bir sergide yer aldıkları Prof. Zehra Çobanlı'nın turkuaz çalışmalarını çok dikkate değer bulmaktadır.

Vukicevic genel anlamda üretim sürecini, amacını ve hedeflerini ise kısaca şöyle özetlemektedir:

“Geçmişin gelenek ve kültürüne saygıyla, geleceğin maceralarına doğru çabalıyorum. İnsan uygarlığının dinamik gelişimine ve onun ayrılmaz bir parçası olarak bireyselliğe, hayal gücüne, duygulara, yaratıcılığa ya da kil, ateş ve su hakkındaki hisleri terk etmeyecek seramiklere inanmak istiyorum. Kendimi sınırlamak için Çöp, Kutular ya da Evren gibi temalar seçerek bu konularda ne yapabilirim diye düşünüyorum. Bir seramiği şekillendirmeye başladığımda her zaman bir sonraki için fikirlerim var. İleride heykel ile duvar çaış̧malarını birleştirmek istiyorum."(Vukicevic, 2014: Internet ortamında yapılan röportaj, 03 Nisan. ).

\section{Sonuç}

Optik yanılsama ülkemizdeki seramik sanatçıları tarafından da özellikle son yıllarda sıklıkla kullanılmaktadır. Bu sanatçılara Oya Aşan Yüksel, İsmet Yüksel, Pınar Baklan Önal, Kamuran Özlem Sarnıç gibi isimler örnek verilebilir. Sanatçılar öncelikle estetik kaygıyla ve eserin izleyicide yaratacağı etkiyi göz önüne alarak iki boyutlu ve üç boyutlu çalışmalarında bu tekniği başarılı bir şekilde uygulamışlardır. Akademik anlamda da bu konuda tamamlanmış yüksek lisans (Baklan Önal, 2011) ve sanatta yeterlik (Sar- nıç, 2011) tezlerinin yanı sıra devam etmekte olan çalışmalar bulunmaktadır.

Çok zengin bir ifade biçimi olan yanılsama, seramik malzemenin kendi şekillendirme ve renklendirme zenginliği ile birleştiğinde kuşkusuz sanatçıya sonsuz olanaklar sunmaktadır. Seramik sanatı, hem geleneği hem de teknolojisi olan bir dal olarak, sanatçı, sanat eseri ve izleyici üçgeninde şekillenen yanılsama için kuvvetli bir alan oluşturur. Herhangi bir kavramsal içerik veya bir mesaj taşıma endişesi olmaksızın üretebilmenin getirdiği özgürlükle hareket eden sanatçı sanatsal öğeleri kendi üslubuyla birleştirerek yorumlayabilir.

Bu anlamda Vukicevic, müthiş bir çalışma enerjisi, şekillendirme aşamasında malzemenin plastik değerlerini ustaca kullanarak parça bütün ilişkisindeki kurguları, desenleri, yüzey boyama tekniğiyle şekillendirdiği özgün eserleri ile her zaman adından söz ettirmeye ve örnek bir sanatçı olmaya devam edecektir (Resim 11).

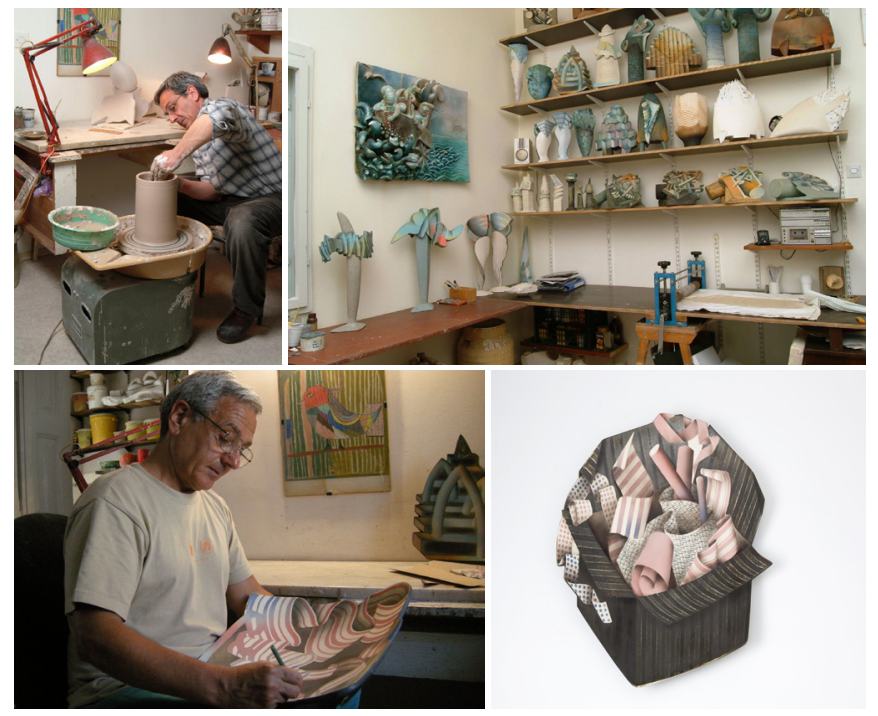

Resim 12. Velimir Vukicevic atölyesinden genel görünüm. 


\section{Notlar}

1 Felsefi Taoculuğun ikinci ismi olan Chuang-Tzu'nun milattan önce 4.yüzyılda yaşadığı bilinse de tarihler konusunda net bir bilgi yoktur. Onun dönemine kadar Taoculuk Sarr Hakan'ın ve Lao-Tzu'nun öğretisi olarak bilinirdi. Ancak bu yüzyıldan sonra, bu felsefenin genel adı 'Lao-Tzu ve ChuangTzu öğretisi' olarak anılagelmiştir. Ve ona 'kelebek filozof' da denmesine neden olan mesele: Chou (Chou, Chuang-Tzu'nun asıl adı), bir gün kelebek olduğunu gördü düşünde... Sevinçle kanat çırpan, mutlu, Chou diye birinden haberi bile olmayan bir kelebek... Uyanıverdi birden, işte yeniden Chou olmuştu. 'Acaba Chou mu gördü kelebek olduğunu düşünde, yoksa kelebek mi Chou olduğunu düşleyen...?' (http://nedir.antoloji. com/chuang-tzu/, 03.11.2014).

\section{Kaynakça}

Ambrose, G., Haris, P. (2005). Grafik Tasarım Temelleri Dizisi: 06, İstanbul: Literatür Yayınları.

Avcı Tuğal, Sibel (2012), Oluşum Süreci lçinde Op Art, İstanbul: Hayal Perest Yayınları.

Baklan Önal, Pınar (2011), Çağdağ Seramik Form ve Yüzeylerde Görsel Yanilsamalar,

Yüksek Lisans Tezi, Ankara: Hacettepe Üniversitesi Sosyal Bilimler Enstitüsü Seramik Ana sanat Dalı.

Ching, Francis D. K., (2003), Mimarlık ve Sanatta Yaratıcı Bir SüreçÇizim, İstanbul: Yem Yayın.

Eczacıbaşı Sanat Ansiklopedisi 3 (1997), İstanbul: Yem Yayın.

Gombrich, E. H. (1992), Sanat ve Yanılsama, İstanbul: Remzi Kitabevi.

Özmen, Gülfidan (2010). Optik Sanat ve Çağdaş Cam Sanatı, Yayımlanmamış Yüksek Lisans Tezi, İstanbul: Mimar Sinan Güzel Sanatlar Üniversitesi.

Radic, Nenad (1999). Sergi Katalog Yazısı, Pero Sanat Merkezi. Belgrad, Sirbistan.

Sarnıç, Kamuran Özlem (2011). Optik Yanılsama ve Seramik Sanatında Kullanımı

Uygulamaları, Yayınlanmamış Sanatta Yeterlik Tezi, Eskişehir: Anadolu Üniversitesi Güzel Sanatlar Enstitüsü.

Vukicevic, Velimir (2014).Internet ortamında yapılan röportaj, 03 Nisan.

\section{Internet Kaynakları}

http://www.vam.ac.uk/content/articles/c/ceramics-points-ofview-elizabeth-fritschs-optical-pot/ (2014)

http://nedir.antoloji.com/chuang-tzu/ (2014) http://velimirvukicevic.com/ (2014)

http://www.arts.bg.ac.rs/rektoraten/ (2014)

\section{Görsel Kaynaklar}

Resim 1.Jan Van Eyck“Müzik Çalan ve Şarkı Söyleyen Melekler”, $161 \times 69 \mathrm{~cm}, 1432$ http://www.artbible.info/art/large/449.html (2014-10-25)

Resim 2. Elizabeth Fritsch, 'Optical Pot', stoneware, yükseklik 311mm, genişlik 232mm, 1980. Museum no. C.13-1981 http://www.vam.ac.uk/content/articles/c/ceramics-pointsof-view-elizabeth-fritschs-optical-pot/

Resim 3. Jason H Green, 'Recovered Geometry No. 9', kırmızı kil, astar, sır, 24.5" x 36" x 3", 2013, http://jasongreenceramics. com/home.html (2014)

Resim 4. Yasuo Hayashi http://www.daiichiarts.com/art_detail. php?arttypeid $=1 \&$ artid $=70$

Resim 5. Jin Eui Kim, http://www.jineuikim.com

Resim 6. Simcha Even-Chen, Plaka tekniği, Terra sigillata, Raku, 17 x 80 x $40 \mathrm{~cm}$ (Y x G x d), 2008 Fotoğraf: Ilan Amihai, http:// www.simcha-evenchen.com

Resim 7. Greg Payce, http://www.gardinermuseum.on.ca/My\%20 Files/Raphael\%20Yu\%20Centre/publications/greg\%20 payce\%20catalogue-complete.pdf

Resim 8. Velimir Vukicevic, 'Dönen Yanılsama' Tabaklar Serisinden, 2013-2014 Velimir Vukicevic arşivinden.

Resim 9. Velimir Vukicevic, Kutular Serisi, 2013-2014, Velimir Vukicevic arşivinden.

Resim 10. Velimir Vukicevic, Kutular Serisi, 2013-2014, Velimir Vukicevic arşivinden.

Resim 11. Velimir Vukicevic, Porselen Heykeller, 2013-2014, Velimir Vukicevic arşivinden.

Resim 12. Velimir Vukicevic atölyesinden genel görünüm. Velimir Vukicevic arşivinden. 